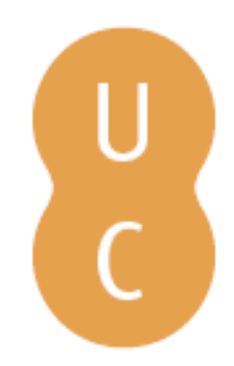

\title{
nommalina
}

\section{FireCCI50: a global burned area mapping algorithm based on MOD09GQ within Fire_cci project}

\author{
Autor(es): $\quad$ Lizundia-Loiola, Joshua; Otón, Gonzalo; Ramo, Ruben; Chuvieco, Emilio \\ Publicado por: Imprensa da Universidade de Coimbra \\ URL \\ persistente: URI:http://hdl.handle.net/10316.2/44697 \\ DOI: $\quad$ DOI:https://doi.org/10.14195/978-989-26-16-506_180 \\ Accessed : $\quad$ 26-Apr-2023 12:29:23
}

A navegação consulta e descarregamento dos títulos inseridos nas Bibliotecas Digitais UC Digitalis, UC Pombalina e UC Impactum, pressupõem a aceitação plena e sem reservas dos Termos e Condições de Uso destas Bibliotecas Digitais, disponíveis em https://digitalis.uc.pt/pt-pt/termos.

Conforme exposto nos referidos Termos e Condições de Uso, o descarregamento de títulos de acesso restrito requer uma licença válida de autorização devendo o utilizador aceder ao(s) documento(s) a partir de um endereço de IP da instituição detentora da supramencionada licença.

Ao utilizador é apenas permitido o descarregamento para uso pessoal, pelo que o emprego do(s) título(s) descarregado(s) para outro fim, designadamente comercial, carece de autorização do respetivo autor ou editor da obra.

Na medida em que todas as obras da UC Digitalis se encontram protegidas pelo Código do Direito de Autor e Direitos Conexos e demais legislação aplicável, toda a cópia, parcial ou total, deste documento, nos casos em que é legalmente admitida, deverá conter ou fazer-se acompanhar por este aviso.

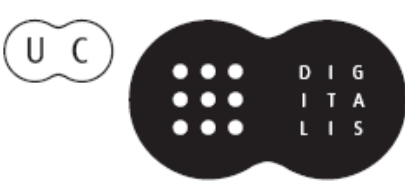




\section{ADVANCES IN}

\section{FOREST FIRE RESEARCH}

\section{8}

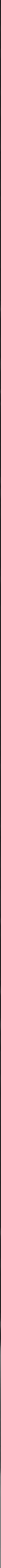


Short contribution - Decision Support Systems and Tools

FireCCI50: a global burned area mapping algorithm based on MOD09GQ within Fire_cci project

Joshua Lizundia-Loiola*; Gonzalo Otón; Ruben Ramo; Emilio Chuvieco

Geography Department, Universidad de Alcalá.Colegios 2, 28801, \{joshua.lizundia@uah.es*, gonzalo.oton@uah.es,ruben.ramo@uah.es,emilio.chuvieco@uah.es\}

Keywords: Burned area, MODIS, Hotspots, algorithm

\section{Introduction}

Fire is one of the main contributors of greenhouse gases and aerosol emissions and it is closely related to carbon cycle (van der Werf et al., 2010). It has a clear influence in global vegetation dynamics and its effect in human property and lives is increasing.

As a result, it is considered an Essential Climate Variable (ECV) and it is deeply investigated within the Fire_cci Project. In the aim of contributing to the Global Climate Observing System (GCOS) programme, the European Space Agency (http://cci.esa.int/, las accessed March 11, 2018) created the Climate Change Initiative (CCI), in which 13 ECV are studied (Fire Disturbance, among others).

\section{Methods}

\subsection{Framework}

Hybrid algorithms have proved to be appropriate to burned area (BA) detection. Two of the most used global BA products, MCD64 (Giglio et al., 2009) and MERIS Fire_cci v4.1 (FireCCI41) (AlonsoCanas y Chuvieco, 2015), have been generated based on this approach. They combine the effectiveness of thermal anomalies products to detect active fire position, with the reflectance changes that affect to the complete BA. The algorithm presented on this paper continues the steps of its predecessor, FireCCI41, using a two steps hybrid approach, with a seed detection phase and a growing phase.

\subsection{Input images and spectral indices}

This algorithm is based on the sensor MODIS (MOderate Resolution Imaging Spectroradiometer) MOD09GQ product (250 $\mathrm{m}$ resolution) and the MCD14ML active fire product. The former one is distributed in tiles of $1200 \times 1200 \mathrm{~km}$ and the second one globally. In addition to the MODIS NIR band, Global Environmental Monitoring index (GEMI) was computed (Pinty y Verstraete, 1992) which proved being a good index to BA detection among the spectral indices based on NIR-Red bands (Alonso-Canas y Chuvieco, 2015). GEMI was computed as follows:

$$
\begin{aligned}
& \text { GEMI }=\eta \cdot(1-0.25 \cdot \eta)-\frac{\left(\rho_{R}-0.125\right)}{\left(1-\rho_{R}\right)} \\
& \eta=\frac{2 \cdot\left(\rho_{N I R}{ }^{2}-\rho_{R}{ }^{2}\right)+1.5 \cdot \rho_{N I R}+0.5 \cdot \rho_{R}}{\left(\rho_{R}+\rho_{N I R}+0.5\right)}
\end{aligned}
$$

where $\rho_{\text {NIR }}$ is the Near Infrared (MODIS band 2) and $\rho_{R}$ is Red (band 1).

As auxiliary data, Land Cover CCI product v1.6.1 (https://www.esa-landcover-cci.org/, last accessed March 11, 2018) was also used, which permitted obtaining a burnable - unburnable mask. 


\subsection{Composite}

Due to the strong BRDF (Bi-Directional Reflectance Distribution Function) effect of MODIS sensor (swath dimension of $2330 \mathrm{~km}$ ) several approaches to reduce it were tested. However, the smoothing effect of those techniques weakened too much the temporal trend of burned pixels. So temporal compositing is used to reduce that angular effect and enhance burned signal.

Two criteria were used to perform the composites: the assignation of the nearest active fire (also called hotspots or HS) date based on Thiessen matrix (Brassel y Reif, 1979) and the selection of the proper minimum NIR value. As BA is expected to have very low NIR values (Alonso-Canas y Chuvieco, 2015) 3 minimum values are searched within a given month. However, this low NIR values can be caused by other events like cloud, topographic shadows or flooding. To avoid possible noise caused by the mentioned events the algorithm selects the first minimum after the date of HS detection. If all the minimums are found on previous dates, the second minimum is selected. At the same time, maximum GEMI of the month (GEMI_max) and GEMI of the selected days for the composite (GEMI_month) are calculated.

\subsection{Seed phase}

The objective of this first phase was to reduce commission errors by selecting those HS that have high probability of being burned. Therefore, Cumulative Distribution Function was computed for unburned class using those pixels of the composite that are further than a $41 \mathrm{x} 41$ window around each HS. The first decile (10\%) is selected as threshold (TH_NIR) and NIR values have to be below it. Second, pixels have to show NIR value decrease between $t$ and $t-1$. Finally, the third condition is that 5 of the 8 surrounding pixels ( $3 \times 3$ window) has to fulfil the two previous conditions to ensure spatial correlation of burned tendencies. The statistic were performed for each tile, biome and month.

\subsection{Growing phase}

Although active fire products have accurate location of fire, this position is related only with those areas that were burning during satellite pass, so many authors have used contextual algorithms for BA mapping (Bastarrika et al., 2011; Alonso-Canas y Chuvieco, 2015) in order to reduce omission error.

An additional variable is used to stop the region growing process (Zhang et al., 2005). To do so, difference between GEMI_max of the previous month and GEMI_month of the current month (difGEMI) were used. The first one represents the maximum greenness of the immediate pre-fire conditions, while the second one shows the vegetation after burning date. The higher the difference was the higher probability of being burned.

To estimate an adequate threshold for difGEMI, CDFs for burned and unburned classes are calculated. The mean of the decil 9 of unburned class and decil 1 of burned class is computed and used as difGEMI threshold (TH_difGEMI).

A pixel is classified as burned if (1) it has a NIR value below TH_NIR, (2) a difGEMI value over TH_difGEMI, (3) a lower NIR value than the previous month (t-1) and (4) at least one pixel seed or burned pixel in a $3 \times 3$ window.

\section{Results}

A new global BA product has been generated based on this algorithm (ftp://anonftp.ceda.ac.uk/neodc/esacci/fire/data/burned_area/, last accessed March 11, 2018). The time series goes from 2001 to 2016 improving the existing ESA BA products and also the spatial resolution offered by the current BA products (500 m MCD64 and 300 m FireCCI41).

The product assessment was performed using a set of global validation sites, taking into account the diversity of fires all over the world and also through the time series. In addition, an intercomparison 
with other existing products has been developed. FireCCI50 product shows a reduction of $10 \%$ in both commission and omission errors in comparison to FireCCI41, but 10\% higher than MCD64 c6. The estimation of burned area is similar to the trends observed in other products.

\section{Bibliography}

Alonso-Canas, I. \& Chuvieco, E. 2015. Global Burned Area Mapping from ENVISAT-MERIS data Remote Sensing of Environment, 163, 140-152.

Bastarrika, A., et al 2011. Mapping burned areas from Landsat TM/ETM+ data with a two-phase algorithm: balancing omission and commission errors. Remote Sensing of Environment, 115, 1003-1012.

Brassel, K. E. \& Reif, D. 1979. A procedure to generate Thiessen polygons. Geographical Analysis, 11(3), 289-303.

Giglio, L., et al 2009. An active-fire based burned area mapping algorithm for the MODIS sensor. Remote Sensing of Environment, 113(2), 408-420.

Pinty, B. \& Verstraete, M. M. 1992. GEMI: a non-linear index to monitor global vegetation from satellites. Vegetatio, 101, 15-20.

Van Der Werf, G. R., et al 2010. Global fire emissions and the contribution of deforestation, savanna, forest, agricultural, and peat fires (1997-2009). Atmospheric Chemistry and Physics, 10, 1170711735 .

Zhang, Q. F., et al 2005. A semi-automatic segmentation procedure for feature extraction in remotely sensed imagery. Computers \& Geosciences, 31(3), 289-296. 